\title{
The opportunity structure, group characteristics, and strategy of ketok magic repair shops in Manado
}

\author{
Struktur kesempatan, karakteristik kelompok, dan strategi bengkel ketok \\ magic di Manado
}

\author{
Antonius Purwanto \\ Department of Sociology, Faculty of Social and Political Sciences, Universitas Sam Ratulangi \\ Address: Kampus Unsrat Street, Bahu, Manado, North Sulawesi 95115 \\ E-mail: antonius.purwanto@unsrat.ac.id
}

Article History: Received 16 June 2020; Accepted 05 August 2021; Published Online 28 August 2021

\begin{abstract}
The increase in internal migration has led to the emergence of ethnic minority migrant groups who work as entrepreneurs in various migration destinations in Indonesia. The migration that occurred in Manado shows that ethnic groups from certain regions form a unique group in the social network of repair shop owners and workers. This study aimed to describe the emergence and development of a ketok magic repair shop business in Manado which is owned by migrants from Blitar City, East Java. This study used a qualitative research method. Primary data were obtained from interviews and observations, while secondary data were obtained from literature studies. The results show that the opportunity structure in the form of requests for car repair and painting services as well as the ease of setting up a repair shop business has enabled the establishment of a number of ketok magic repair shops in Manado. Ethnic characteristics in the form of communities with high solidarity and strong social networks support repair shop activities well. This study concludes that community and social networks facilitate recruitment of workers and carry out repair shop promotion strategies because of high solidarity.
\end{abstract}

Keywords: ethnic entrepreneurs; group characteristics; opportunity structure; strategy

\begin{abstract}
Abstrak
Peningkatan migrasi internal telah menyebabkan munculnya kelompok migran etnis minoritas yang bekerja sebagai pengusaha di berbagai daerah tujuan migrasi di Indonesia. Migrasi yang terjadi di Manado menunjukkan bahwa etnis dari daerah tertentu mengelompok membentuk keunikan dalam jaringan sosial pemilik dan pekerja bengkel. Studi ini bertujuan mendeskripsikan kemunculan dan pengembangan bisnis bengkel ketok magic di Manado yang dimiliki oleh para migran dari Kota Blitar, Jawa Timur. Studi ini menggunakan metode penelitian kualitatif. Data primer diperoleh dari wawancara dan observasi, sedangkan data sekunder diperoleh dari studi literatur. Hasil penelitian menunjukkan bahwa struktur kesempatan dalam bentuk permintaan untuk perbaikan mobil dan layanan pengecatan serta kemudahan mendirikan bisnis bengkel memungkinkan pendirian sejumlah bengkel ketok magic di Manado. Karakteristik etnik dalam bentuk komunitas dengan solidaritas tinggi dan jejaring sosial yang kuat mendukung kegiatan bengkel dengan baik. Studi ini menyimpulkan bahwa komunitas dan jaringan sosial memudahkan perekrutan tenaga kerja dan melakukan strategi promosi bengkel karena solidaritas yang tinggi.
\end{abstract}

Kata kunci: pengusaha etnik; karakteristik kelompok; struktur kesempatan; strategi

\section{Introduction}

Internal migration is the movement of people between regions within a country. According to Sukamdi \& Mujahid (2015), an increase in internal migration between provinces in Indonesia occurred between 2005 to 2010. Rangkuti (2016) argued that migrants have a greater ability to improve living standards and lift themselves out of poverty. Higher wages received following migration provide many opportunities for migrants. The increasing of the level of welfare also allows them to have the power to support new migrants who can potentially maintain the flow of migration in the future. Indonesia consists of 34 provinces and has 1.340 ethnic groups. Each province usually has one dominant or majority ethnic 
groups such as the Sundanese in West Java and the Minangkabau in West Sumatra. The increased internal migration between provinces led to the emergence of other ethnic groups that became minority ethnic groups in each province of migration destination. These ethnic migrant groups usually live in the provincial capital and regency or city capitals.

Sukamdi \& Mujahid (2015) stated that between 2005 to 2010, the number of migrants entering and leaving North Sulawesi was balanced. Initially, the inhabitants of Manado City, the capital of the North Sulawesi Province, consisted of the Minahasa, Chinese, Sangihe-Talaud, Gorontalo, and Ternate ethnic groups. This can be understood because Manado is the capital of North Sulawesi Province. Eventually, there are residential areas called the Kampung Bugis, the Kampung Ternate, et cetera. The presence of Javanese in Manado is easily recognized through their businesses such as Martabak Tegal, Warung Lamongan, Bakso Solo, and Bakso Arema, where the majority of them sell food. In Manado, migrants from Java were not concentrated in certain areas but spread among the locals. They do not form ethnic enclaves. This article focused on the Javanese ethnic group in Manado, more specifically focusing on the ketok magic repair shop which is generally run and owned by migrants from Blitar City, East Java. The ketok magic repair shop business is interesting to study because it spreads in various cities in Indonesia. This article was based on the results of a study with the following statement of the problem: How do the ketok magic repair shop business arise and develop in Manado City?

The terms ethnic entrepreneurs or ethnic minority entrepreneurs and middleman minority are familiar in the study of entrepreneurship. Ethnic groups are groups whose members have awareness as members of the group and share similar origins and cultures, or who are seen to have these attributes by others (Yinger 1985). Entrepreneurs are people who own and run business activities (Greenfield et al. 1979). This includes people who run businesses by employing family members and other people. The relationship among ethnic entrepreneurs is "a set of connection and regular patterns of interaction among people who share common national background or migration experiences" (Waldinger et al. 1990). This definition is used in the context of the United States where the existing ethnic entrepreneurs come from other nations or countries such as Latin Americans and Asians. Discussing ethnic entrepreneurs in Indonesia, this article defines ethnic entrepreneurs as a group of people who own and run businesses and have the same ethnic background. Middleman minority is a minority group that occupies the middle position in the social structure that becomes the link between the producer and the consumer or the liaison between the elite and the masses.

Research on ethnic entrepreneurship began when many Asian and South American immigrants came to the United States. Some writers described the causes and development of ethnic minority entrepreneurs. Light (1972) pointed out that ethnic entrepreneurs emerged because local people refuse to work in certain occupations or ethnic minority groups can offer goods at lower prices. By working independently, they earn a higher income and status reward compared to locals who are more fortunate in the labor market. Bates (2011) pointed out that a combination of discrimination, blocked mobility, a lack of better employment alternatives pushes immigrants toward entrepreneurship. Alund (2003) said that highly educated ethnic minorities desire to attain decent employment but they face difficulties because of the majority ethnic culture's view that ethnic minorities are better suited with jobs that require more physical strength. Razin (2002) said that the opportunities provided by the environment of a host society have a strong influence on the propensity of immigrants to turn to self-employment as a way of absorption and upward economic mobility. These external factors affect a variety of ethnic and immigrant groups in various ways. Volery (2007) showed that entrepreneurs who serve orders are easy to move and allow them to return to their homeland. This can be accomplished by acquiring skills or assets that can readily be transferred across geographic regions. Commonly, immigrants acquire the skills and capital needed to start an enterprise while employed. Assudani (2009) said that in-group ties are indeed a useful platform for overcoming challenges in forming and supporting business activities although the same ties can also limit efforts to build business activities. However, some institutions or organizations can also act as a structural hole to compensate for in-group ties that hinder business development. A structural hole is a weak network that connects two strong networks. People in this weak 
network behave and think differently than those in groups with strong networks (Burt 2004). They have new ideas or information and other economic benefits. Veciana (2007) said that besides serving as a driving force to work independently, a marginal social position also serves as a way to gain recognition and social equality.

Based on a review of existing writings, Edna Bonacich (1973) found two reasons why ethnic minorities choose to become entrepreneurs, i.e., first, the local community does not like the cultural characteristics of the minority groups so that they are prevented from working in jobs that are preferred by the local community and they are willing to do low-level jobs. Second, the existing status gap in society divides the status of the elite and the masses, which is between the elite of landlords and peasants or between the indigenous population and representatives of the colonial rulers in the colonial period. The intermediary group filled the gap to bridge the two different classes. However, Bonacich disagreed with these two causes. He argued that, first, the attitude of anger and discrimination against minority groups does not make these groups rise to the middle position but rather causes them to descend to the bottom of the socio-economic stratification ladder. Second, the gap in society between the upper and lower classes still exists, even in postcolonial societies, but the majority of trading groups remain in the middle position (Bonacich 1973). Then, Bonacich put forward an alternative view that the Sojourner effect influences the existence of ethnic minority groups who are active in economic activities or are commonly referred to as ethnic entrepreneurs. Minority intermediary groups were originally migrants, i.e, people who moved to a place for a specific purpose and did not want to stay permanently in that place. However, whether in the end, they want to stay permanently or not is an empirical question that needs to be researched.

Sojourning is a necessary condition due to economic and social consequences that can form a middleman group (Bonacich 1973). The economic effect concentrates on certain jobs and frugal behavior. Thrifty behavior is a product of an act of willingness to bear a difficult life for the long-term goal of returning to one's hometown. The action is manifested in the form of working with longer hours, continuously, and less money and time spent for consumption. Sojourning is pushing one to choose jobs that do not make $\mathrm{him} /$ her bound to a territory for a long time. Bonacich showed how the sojourner effect caused members of ethnic minority groups to enter the role of middleman in the economic structure. Based on a review of the writings on ethnic entrepreneurship, Howard Aldrich and Roger Waldinger stated that the conditions cause ethnic minority groups to engage in economic activity and become minority middlemen (Aldrich \& Waldinger 1990). They explained that first, the opportunity structure is a market condition such as the presence or absence of demand for goods or services produced by ethnic minority trade groups. Access to ownership is included in the category of opportunity structure. Two conditions affect access, including 1) the level of competition between ethnic groups to get a job or business, and 2) state policy (Aldrich \& Waldinger 1990). Second, group characteristics are those that allow certain ethnic groups to disproportionally concentrate on ethnic endeavors. Two elements of group characteristics are 1) predisposing factors in the form of expertise and group goals that can be used to exploit opportunities, and 2) resource mobilization factors in the form of capital use and social networks (Aldrich \& Waldinger 1990). Third, ethnic strategy is the act of positioning oneself in front of other parties in order to achieve goals. This ethnic strategy is the result of the interaction of opportunity structures and group characteristics (Aldrich \& Waldinger 1990). To explain the emergence and development of the ketok magic repair shop business in Manado, this article used the concepts of opportunity structure, ethnic characteristics, and strategies in the framework designed by Aldrich and Waldinger.

This study aimed to describe the emergence and development of the ketok magic repair shop business in Manado which is owned by migrants from Blitar City, East Java. This research on minority entrepreneurs is significant because, in Indonesia, various ethnic groups are living in various regions or islands. In these places, they become the dominant or majority ethnic group. The increasing mobility of the population as a result of better transportation and communication facilities has led to the arrival of newcomers who take advantage of existing opportunities to open businesses. Eventually, the migrants become an ethnic minority group in the new places, resulting in ethnic minority entrepreneurs. For example, Bugis people become ethnic minority entrepreneurs in Papua or Sangihe-Talaud, Javanese people become 
ethnic minority entrepreneurs in Bolaang-Mongondow or Palangkaraya and Ternate, and so on. It can be predicted that in the future there will be more and more ethnic minority entrepreneurs in many regions in Indonesia. Although there are many ethnic groups in the country, each of them has different tendencies in making decisions to become entrepreneurs and determining destinations to run their businesses. For example, ethnic Batak, Chinese, Balinese, South Sumatran, and Minang have different tendencies in choosing where they will run their business. Ethnic Batak, Chinese, Balinese, and South Sumatran prefer to be entrepreneurs and run their businesses in their native area. On the other hand, the Minang ethnic prefers to be entrepreneurs and run outside their native area. Cultural influences determine where each ethnic group chooses to run their business as entrepreneurs (Cahyono et al. 2021). Bugis and Javanese people also seem to tend to be like the Minang ethnic to become entrepreneurs outside their native areas because of the extremely pressing situation.

\section{Research Methods}

The research on the ketok magic repair shop was conducted using a qualitative research method. Data was collected by using in-depth interview and observation techniques. Interviews were conducted with 15 repair shop owners and workers. Meanwhile, observations were made in the repair shop to observe the work process, the way they cooperate, and the repair shop environment. Longer observations were made in the repair shop with many workers. This study also used secondary data in the form of online local newspapers to determine the number of public and private vehicles in North Sulawesi. Information on the growth of internal migration into and out of North Sulawesi was also used secondary data.

The data were analyzed by considering the general trend of the answers given by the informants. The observed trends include the number of times owners and workers move from one city to another before finally working in Manado, tendency to act in general which can be concluded as social norms that must be obeyed by the repair shop owners and workers, patterns of interaction between repair shop owners and the surrounding community, and so on. This research was officially conducted in January and February 2019 in Manado City and its surroundings. However, outside this time span, this study also conducted interviews and observations to add the required information.

\section{Results and Discussion}

\section{Opportunity structure}

The opportunity structure provides opportunities for migrant groups to work for others or set up their own businesses. The opportunity structure for ketok magic repair shop entrepreneurs is the lack of repair shops that provide car body repair and painting services and the increasing number of car ownership. In Manado, people prefer to use public transportation as a means of transportation. Prior to the 1990s, public transportation services were served by pick-up cars with a capacity of seven passengers. Starting in the 1990s, pick-up vehicles were replaced with station wagons with a carrying capacity of nine people. The small number of private cars and motorbikes in Manado makes vehicle traffic run very smooth. Traffic accidents and even sideswipe collisions between cars are also rare. There are only two to three car body painting repair shops owned by locals. Car painting often takes a long time and the results are not good. The situation began to change after entering the 2000s. The increase in private car ownership began to occur in 2010. The increase in the number of private car ownership seems to be closely related to the ease of buying cars and motorcycles on credit. The increase in the number of private cars is particularly noticeable when commuting to and from work in the morning and evening. The number of private vehicles has exceeded that of public transport vehicles.

In North Sulawesi, the number of vehicles in 2017, 2018, and 2019 was 714.031, 774.991, and 808.258 units, respectively. Of the total 808.258 units in 2019, the two-wheeled vehicles were 608.869 units (Kumparan 2019). In Manado, the number of four-wheeled vehicles in 2015 was 86.000 units and increased to 123.227 units in 2017 (Jerry 2015). As of the end of 2015, the length of the vehicle was 
1.711.250 kilometers with a road length of only 518,830 kilometers and an average width of 3 to 10 meters. Therefore, a road with a length of 1.191,24 kilometers is still required. In such conditions, it can be understood that the road becomes increasingly congested. In 2018, the average vehicle speed in Manado was 25 to 35 kilometers per hour and during traffic jams, the average speed was between 0 to 10 kilometers per hour (Finneke 2018). Such traffic condition increases the likelihood of accident between the cars, causing damage to the car body. This damage certainly needs repair.

The first ketok magic car body repair and painting repair shop in Manado was first opened in 1995. One of its founders, MIN, is experienced in working in ketok magic repair shops in several cities. MIN said:

"We used to work for other people. First, I was in Palu, then Makassar, then returned to Java, then to Bali, then back to Poso, and last to Gorontalo. After Gorontalo, I moved to Manado. People say that there are more cars in Manado. Good. Finally, I came here in 1995. I moved often. Here, I am the first. Previously in Gorontalo, I just joined other people. We founded here in 1995. In the past, three people together set up the repair shop. Now they have moved and set up their own repair shops."

In Manado, the owners or entrepreneurs of the repair shops from Blitar can be said to have no competitors except among their peers. There are now 16 repair shops from Blitar in Manado and its surroundings. Although there are also repair shops in other cities in North Sulawesi, such as Bitung, Kotamubago, and Tomohon, some cars from these cities are repaired in Manado instead. Existing repair shops generally employ four or eight workers who are skilled or still in the apprenticeship process. The Armada Siaga repair shop is the largest one in Manado employing 35 workers plus several administrative staff to set up a repair shop, owners rent land to locals with rental prices varying, depending on whether the location is strategic or not. There are three repair shops whose land is bought from local residents. The average size of the repair shop area ranges from 300 to 500 square meters. In general, the repair shops have land for car parking without a roof and simple roofed buildings for the process of repairing and painting cars that need shade. Then, there is a space usually used to store equipment and used by workers to rest or sleep. Workers usually sleep in the repair shop. Only those who are married or married to a Manado native, who represent a small proportion of the population, live in their own homes. Armada Siaga has a fairly large land area with a modern building. The building is divided into administrative office space and car repairs and painting rooms. This repair shop also provides shelter for its workers.

It is easy for migrants from Blitar to set up a repair shop because there are no institutional or normative obstacles. What is needed for people who want to set up a repair shop is to have a business license from the Manado City government. To get the license, one must have a resident identification card (KTP), tax identification number (MPWP), and approval from neighbors. Permission to build a building (IMB) or environmental feasibility (AMDAL) from the environmental service are not required to set up a repair shop. In general, repair shop owners have a high school education background. Because of the cultural gap between the repair shop owners and the bureaucratic apparatus, in general, the repair shop owners ask for help from people they know to take care of the permit to build a repair shop. For example, they might ask for help from police or civil servants who come from Java.

Usually, repair shops install simple signboards with telephone numbers (cell phones) to facilitate communication with car owners who want to repair their cars. The signboard uses names like the ketok magic repair shop of Artomoro, Putra Blitar, Armada Siaga, and so on. Initially, car owners with strong religious beliefs were hesitant to come to the repair shop because they thought that car repairs at the ketok magic repair shop were done using the power of the devil. The ketok magic repair shops are usually a bit closed when compared to usual repair shops. To dispel the doubts of car owners, repair shop owners usually invite them to see for themselves how the car repair process is done without using magical power. The Armada Siaga repair shop replaces the term ketok magic with the term dodok halus to avoid the impression of the connotative meaning of using magic power from the term ketok magic. Eventually, the car owners are no longer hesitant to repair their cars in the repair shop. 
Certain actions in achieving goals can be hindered or facilitated by institutions (North 1991, Ingram \& Clay 2000). The repair shop owners do not experience any institutional barriers in setting up their repair shop business because they can meet the licensing requirements set by the Manado City government. With the fulfillment of these conditions, they can run their business safely. They get certainty and protection of property rights. In a study of the ceramic craft cluster in Kasongan, Yogyakarta, one of the obstacles for small entrepreneurs to export their products is that their business is not a legal entity yet. To overcome these obstacles, small entrepreneurs set up cooperatives. With these cooperatives, they can export their products. Otherwise, they have to sell their products to existing exporters or to big businessmen whose business is legal (Purwanto 2013). The importance of institutions in supporting business activities is also demonstrated in small-scale gold mining businesses. In Indonesia, this business is generally illegal, making them experience many obstacles and do not receive assistance from the government or development assistance agencies. However, the small-scale gold mining in Tatelu, North Minahasa, has succeeded in improving the welfare of the surrounding community and has received assistance from the government and development assistance agencies from within and outside the country (Purwanto 2020).

\section{Group characteristics: Community and network}

Repair shop owners and their workers do not live in one settlement, but rather in numerous locations across Manado. Because they live in such a dispersed manner, they do not form a kind of local community or neighborhood. This is also the case with other migrants from Lamongan, Malang, Surabaya, and Tegal of Java Island who also live dispersedly. Sociologically, the migrants who work in the ketok magic repair shops form a community of ethnic workers. Robert Nisbet defined that community encompasses all forms of relationship which are characterized by a high degree of personal intimacy, emotional depth, moral commitment, social cohesion, and continuity in time (Day 2006). Ethnic communities function as shelters in overcoming alienation in a different society. They maintain physical and social boundaries. There is social pressure for members of ethnic groups to follow the customs, beliefs, and values of the group (Bruhn 2011). In Manado, a successful repair shop owner is said to be a deviant because he/she associates more with high-status local people rather than repair shop owners.

In Manado, the smallest social network is the one between owners and workers in one repair shop. Efforts are made by the repair shop owners and their workers to maintain the Blitar ethnic community. To maintain a sense of brotherhood and solidarity, the repair shop owners and workers hold regular meetings once a month. The place of the monthly meeting is rotated from one repair shop to another. To keep all members present at the monthly meeting, lottery club (arisan) activities are also held. The difference in the amount of money owned by the repair shop owners and workers makes the lottery club groups are divided into two, which are the lottery club of the repair shop owners and the lottery club of the workers. The monthly gathering is informal; the most essential thing is that all members are able to attend. Monthly gatherings are not only conducted by the repair shop owners and workers but also by the wives of the repair shop owners. Besides, to ensure the welfare of the workers, the repair shop owners try to provide health assistance to their workers. This assistance is given to sick workers and family members both in Manado and those in their hometowns in Blitar. For this purpose, the repair shop owners collect a certain amount of money in accordance with the number of workers to the group leader.

Monthly gatherings and other gatherings conducted between repair shop owners and between workers in accordance with their preferences create a strong sense of solidarity. Complaints or rumors are occasionally used to express the abnormal behavior of certain members. Actions that are considered deviant can be those that are not in accordance with Javanese cultural norms or refusing to attend monthly gatherings. For example, one repair shop owner develops far beyond the average achieved by other repair shop owners and interacts more with the locals than with members of the Blitar ketok magic community. The owner of this repair shop is considered to be deviant, not part of the community, and considered as an outsider. 
Through social interaction in group gatherings and workplaces that use the Javanese language, the community and the ketok magic network are strengthened with a different identity from the locals of Manado. Cultural identity is also strengthened by Javanese songs that are often heard using gadgets at repair shops or monthly gatherings. Javanese who repairs their cars in the Armada Siaga repair shop will immediately feel that they are in Java because Javanese songs are tuned in quite loudly. While working, the workers listen to such songs every day. Some repair shop owners and workers try to keep their children's cultural identity by telling their children to go to school in Java. A worker, HEN, said: "I sent my child to school in Java. I am worried about sending my children to school here. The Association of children here seems too free, not polite. Children seem to disrespect older people".

HEN's action is a form of way to maintain ethnic social boundaries. In Manado, people often do not use designations that indicate whether ones are older or younger when they call people they already know. People often say one's name directly. Most workers usually return to their hometowns in Blitar once a year during lebaran. In Blitar, they can meet with fellow ketok magic repair shop workers who come from various cities in Indonesia. When the researcher visited a repair shop, it still had very little activity because two of its workers had not yet returned from their hometown.

In general, repair shop owners and workers arrive in Manado through existing social networks. Ketok magic social network not only connects repair shop owners and their workers in Manado with the community in their hometown of Blitar but also with repair shop owners and their workers in other cities in Indonesia. Only a few repair shop owners and workers went directly to Manado from their hometown in Blitar to open a repair shop. Before arriving in Manado, most repair shop owners and workers had already worked in other cities. For example, some workers had worked in Bali, Solo, Palu and only then worked in Manado. Therefore, most workers or repair shop owners gain expertise and skills, not in Blitar, but in other cities. Moving from one city to another until finally arriving in Manado is also an indirect process of learning through work practices that increasingly adds to their expertise and knowledge in car repair. The strength of social networks has a positive function for repair shop owners in dealing with people outside the network (Coleman 1988). This strong social network makes it easy for repair shop owners to get paint material easily. For example, if the owner does not have enough money, the paint shop is willing to provide credit without interest. Therefore, social networks are a crucial ethnic resource.

The importance of social networks in supporting migration and entrepreneurship among ethnic minorities is also evident among Madurese migrants in Bogor City. The Madurese migrants came to Bogor at the invitation of the Madurese who had worked in Bogor earlier. In Madura, they are bound as family, friends, or neighbors. Newly arrived migrants usually live and work for Madurese who had a business for a year or two. When new migrants work, they can gain skills in running a business. After having enough capital, they open their own business. When they lack capital, they can borrow money from fellow Madurese (Sasongko \& Wahyuni 2013). The importance of social networks in migration and entrepreneurship is also evident in migrants from Lampung in Krawang, West Java (Safitri \& Wahyuni 2013).

\section{Collective strategy}

Strategy is the act of positioning oneself as a group or as individuals in social structure to maintain or improve position. Meanwhile, ethnic strategy is the result of a combination of opportunity structures and group characteristics. In conjunction with the ketok magic repair shop, strategy means the way to maintain and improve the repair shop business. Both collective and individual strategies are carried out by repair shop owners. The following subsections would describe how the collective and individual strategies are carried out by the repair shop owners.

Collective strategy is a strategy that is the result of mutual agreement, whether realized or not. This strategy is carried out to prevent deadly competition. The establishment of a standard price for repairing 
and painting a car body is one of the collective strategies. Standard pricing will make it easier for repair shop owners to determine the price that must be paid by the consumers without worrying about overcharging or undercharging. Before the price standard is determined, the car body is divided into panels. The panels are, for example, left and right doors, roof, hood, bumpers, et cetera. For example, the cost of repairing and painting a door is IDR 600.000. This fee depends on the color of the paint. If the color of the paint is red, it costs IDR 900.000 because the price of the paint is more expensive than black or white. The standard is an agreement between the repair shop owners and the insurance office that often uses car repair services from the ketok magic repair shops. The standard is used to simplify the calculation of payments by the insurance office because the office usually repairs a large number of cars. Repair shop owners usually do not strictly apply this standard when repairing cars ordered by the owner himself. This is because the damage from each car body is specific so it is difficult to determine the standard cost.

There is also an unwritten agreement between the repair shop owners regarding the cost of painting the entire car body. For example, a small car like Agya costs IDR 7 million, Avanza costs IDR 7-8 million, while Fortuner costs IDR 8-9 million, depending on its size. If the car is changed in color, it will cost differently. Such an order costs more than when the color remains the same because it needs to be painted inside and out. Standardization of goods in the form of panels and costing the repairs makes it easier for consumers to make the decision to choose which place to repair their cars (Beckert 2009). There is no agreement on the price of repairing the chassis and the body of a heavily damaged car because there is difficulty in finding the same levels of damage. However, based on information from a repair shop owner, tolerance was given to the repair shop with few customers. A small repair shop can reduce the cost of painting.

Another collective strategy is carried out in terms of providing wages to workers, which is given in the form of profit sharing. In this revenue sharing, the repair shop owners get a 40 percent share, while the workers get a 60 percent share. The 60 percent is then divided again, depending on the number of workers. Such profit-sharing has been in effect since the first time there was a ketok magic repair shop in Manado and has never changed. According to a repair shop owner, the percentage of profit sharing is different from the one implemented in Java and Bali. In those regions, the profit-sharing between the repair shop owners and their workers is 50:50. In other islands outside Java and Bali, the profit-sharing is the same as in Manado. The consideration is that workers outside of Java and Bali require greater transportation costs to move from Blitar compared to those in Java and Bali. It is easy for workers to find out the percentage of revenue sharing in various cities in Java and Bali as well as outside Java and Bali. Because the profit-sharing between the repair shop owner and the workers has become a collective knowledge or norm between the repair shop owners and their workers, it is difficult to change this deal. Only Armada Siaga repair shop does not implement the profit-sharing system. This repair shop pays its workers monthly. Each month, Armada Siaga is able to repair an average of 300 cars, while other repair shops with four workers can only repair 30 cars on average. This allows Armada Siaga to pay its workers on a monthly basis. Besides, Armada Siaga also has two other repair shops outside Manado.

There is an agreement among the repair shop owners which is also a strategy to avoid competition, which is hiring workers who have worked for other repair shops. Sometimes, one or two repair shops receive many car repair orders. The work can be completed by extending working hours or adding the number of workers. To add workers, there is an agreement that the repair shop owners must ask permission from other owners so that the workers may work temporarily at the repair shop with an excessive number of orders. Such an agreement is crucial to avoid battling over workers by repair shops with many car repair orders and small ones. A community with strong solidarity and a dense network between the owners of the repair shop and the workers make these agreements respected by their members. These agreements become an institutionalized norm that grows spontaneously among community members. The collective agreement shows that institutions can emerge from social networks and are socially constructed (Granovetter 1992, Ingram \& Clay 2000). 


\section{Individual strategy}

Individual strategies are strategies carried out individually by each repair shop owner without being bound by mutual agreement. They are related to the strategies of workers to improve their status to become repair shop owners, to get customers, to improve the quality of car repairs, to develop their business, and to adapt to the social environment where the repair shop is located.

The desire to be independent, free from the domination of others and strong confidence to develop are driving forces for workers to build their own businesses. This happened to informant HAR who originally worked at the first ketok magic repair shop established in Manado. HAR said: "Yes. The idea is, no matter how much money we earn, if we work for other people, we will still have a small income. Our expertise is like being cooped up. Income is definitely limited."

For that purpose, he sought a new location far enough from the repair shop where he worked. Finally, he found a place about three kilometers away from the previous repair shop. The capital of IDR 180 million is used to rent land, build buildings for repair shops, and buy work equipment. His business capital was obtained from savings and loans from a bank. Social networks were important for him in his strategy to get resources. He got his workers through his acquaintances from the repair shops in other cities. The same thing was done by the owner of the Timbul Jaya repair shop. He set up a repair shop in the former repair shop owned by his friend who moved from Manado.

One of the efforts to get continuous car repair orders is to provide satisfactory car repair work for consumers. Various ways are done by each repair shop. For example, at Timbul Jaya repair shop, the owner said that the way to keep consumers coming back is by providing free car washing service for the damaged cars after car repair and a car shuttle service. At the time of the interview, he said his repair shop had customers from employees of one of the government agencies. This could happen because one of his customers was satisfied with the results of his work and advised his friends to go to Timbul Jaya to repair his car. It can be said that information through social networks from consumers is one of the means by which a repair shop can get many consumers. An informant, MIN, said:

"I have never posted advertisements via the internet. The owner of this car always brings his car here when it is damaged. In the past, when his old car is damaged, it was also brought here. This customer tells his friends and relatives to come here. My customers are from Bitung, Tomohon. Some come from Talaud (Talaud Island). So, it's only word of mouth. No need to advertise."

Some repair shops also get customers from the insurance office. To cooperate with the insurance office, the repair owner and the insurance office sign a cooperation contract. With this cooperation contract, the repair shop can get car repair orders continuously. However, small repair shops with four to eight workers are usually unable to maintain such cooperation because they are considered too financially burdensome. The insurance office only pays after the repair shop fixes dozens of the agreed cars. Small repair shop owners find it hard to bear the costs of car repairs because they need to provide the cost of buying paint and payment of workers' wages. It is because the insurance company does not pay 100 percent of the cost of car repairs at the beginning. For example, according to the insurance agreement, they pay 60 percent at first, then the rest is paid after a number of cars are repaired. Only large repair shops such as Armada Siaga are able to survive in cooperation with the insurance office. At the time of the interview, NAN, an informant from Armada Siaga, said that the repair shop worked with seven insurance offices. Therefore, small repair shops can only work with companies or government agencies without a written contract. Such cooperation is based more on mutual trust and direct payment is given after the car has been repaired.

To get legitimacy from the social environment, the repair shop owners feel the need to adjust to the environmental situation and meet existing social expectations. At certain times, such as Independence Day, repair shop owners usually provide financial assistance to the community or local government. They 
also usually contribute to the youth activities of the church or mosque congregation. The existence of the ketok magic repair shops does not cause environmental pollution in the form of waste or noise. Based on information from the informants, no repair shops ever received interference from the surrounding community. Therefore, the assistance is purely based on voluntary feelings. An informant, HAR, said:

\begin{abstract}
"Sharing is important. 'What money is for if we don't share it?' It can be shared with the environment, the church. Asking for donations is normal. Sharing is important as long as we have enough. After all, many fortunes are useless if it is not shared. We have no other intention. The question of security depends on the above (God). Depending on the intention. We have no intention of being safe. The one above (God) knows."
\end{abstract}

Business activities are always located in a certain institutional environment. One of the institutional elements is the normative element (Scott 2014). Business activities must be able to meet the institutional environment. The actions of the repair shop owners to donate on Independence Day as well as to social and religious activities are an attempt to meet these normative demands. In this way, the existence of the repair shops will be accepted by the surrounding community. The act of assisting the surrounding community was also carried out by a cooperative owned by small-scale gold mining entrepreneurs in Tatelu, North Minahasa. These normative expectations are usually not clearly stated by the community around the place of business.

Linking social capital is a network of relationships between people who have low status or do not have power with those who have high status or power. A formal relationship with bureaucratic officials is one form of the social network linking. This network is important for obtaining information and government assistance. In Makassar, ethnic entrepreneurs lack linking social capital (Turner 2007). In Manado, the repair shop owners also lack this kind of network, so they do not get assistance from the government. The repair shop owners only have an informal network with the police or civil servants from Java. Protection from the police seems to be felt by the owners of the repair shop. Some of them have relationships or acquaintances with the police. They usually provide relief for the cost of car repairs to the police, sometimes even not asking for the cost of repairs at all. In return, the repair shop owners ask for help from the police when dealing with them. The need for a sense of security is also evident in the existence of a car repair shop owned by a police officer. The police did not come from Blitar. If he was not police, it would be difficult to be able to set up a ketok magic repair shop because it would be hard to find workers with skills such as Blitar ketok magic workers. This status as a policeman causes him to have a ketok magic repair shop with workers from Blitar.

\title{
Conclusion
}

The increasing number of cars in Manado has led to the emergence of an opportunity structure in the form of increased demand for car body repair and painting services and the absence of institutional and normative obstacles allowing migrants from Blitar to set up ketok magic repair shops. No institutional obstacles are found since the repair shop entrepreneurs can easily meet the requirements for the establishment of repair shops. Characteristics of groups in the form of strong social networks and high community solidarity support the ease of setting up and the running of repair shop activities. Social networks make it easy for repair shop owners to recruit skilled workers to work in their repair shops. Strong solidarity and solid social networks make it easy to form agreements among repair shop owners regarding the standardization of car repair costs.

Standardization is one form of collective strategy. It makes it easier for consumers to make the decision to repair their cars in the repair shop they choose. It can also prevent competition that can harm all repair shops. Profit-sharing agreements for providing wages to workers for a long time can also prevent competition between repair shops. By using individual strategies, each repair shop owner tries to maintain and develop his business. The results of this study indicate that social networks can support the development of informal economic institutions. 


\section{References}

Aldrich HE \& Waldinger R (1990) Ethnicity and entrepreneurship. Annual Review of Sociology 16: 111-135. https://doi.org/10.1146/annurev.so.16.080190.000551.

Alund A (2003) Self-employment of non-privileged groups as integration strategy. International Review of Sociology 13 (1):77-87. https://doi.org/10.1080/0390670032000086998.

Assudani RH (2009) Ethnic entrepreneurship: The distinct role of ties. Journal of Small Business and Entrepreneurship 22 (2):197-205. https://doi.org/10.1080/08276331.2009.10593450.

Bates T (2011) Minority entrepreneurship. Foundations and Trends in Entrepreneurship 7 (3-4):151311. http://dx.doi.org/10.1561/0300000036.

Beckert J (2009) The social order of markets. Theory and Society 38 (3):245-269. https://www.jstor.org/ stable/40587527.

Bruhn JG (2011) The Sociology of Community Connections. New York: Springer.

Bonacich E (1973) A theory of middleman minorities. American Sociological Review 38 (5):583-594. https://doi.org/10.2307/2094409.

Burt RS (2004) Structural holes and good idea. American Journal of Sociology 110 (2):349-399. https:// doi.org/10.1086/421787.

Cahyono E, Syafitri W, \& Susilo A (2021) Ethnicity, migration, and entrepreneurship in Indonesia. Journal of Indonesian Applied Economics 9 (1):1-12.

Coleman JC (1988) Social capital in the creation of human capital. American Journal of Sociology 94 (supplement):195-120. https://www.jstor.org/stable/2780243.

Day G (2006) Community and Everyday Life. New York: Routledge.

Finneke (2018) Kecepatan rata-rata kendaraan di Manado 25-35 kilometer per jam, kemacetan parah bakal terjadi. Tribunnews, 09 July. [Accessed 08 May 2020]. https://manado.tribunnews. com/2018/07/09/kecepatan-rata-rata-kendaraan-di-manado-25-35-kilometer-per-jamkemacetan-parah-bakal-terjadi.

Granovertter M (1992) Economic institutions as social constructions: A framework for analysis. Acta Sociologica 35 (1):3-11. https://doi.org/10.1177/000169939203500101.

Greenfield SM, Strickon A, \& Aubey RT (1979) Entrepreneurs in Cultural Context. Albuquerque: University of New Mexico Press.

Ingram P \& Clay K (2000) The choice-within-constraints: New institutionalism and implications for sociology. Annual Review of Sociology 26: 525-546. https://doi.org/10.1146/annurev.soc.26.1.525.

Jerry (2015) Inilah jumlah mobil di kabupaten dan kota se-Sulut. BeritaManado.com, 18 June. [Accessed 25 May 2020]. https://beritamanado.com/inilah-jumlah-mobil-di-kabupaten-dan-kota-se-sulut/.

Kumparan (2019) Kendaraan di Sulut setiap bertambah 167 unit. Kumparan.com, 16 October. [Accessed 8 May 2020]. https://kumparan.com/manadobacirita/kendaraan-di-sulut-setiap-harinya-bertambah167-unit-1s44n6sG21N/full.

Light IH (1972) Ethnic Enterprise in America: Business and Welfare Among Chinese, Japanese, and Blacks. Berkeley: University of California Press.

North DC (1991) Institutions. Journal of Economic Perspectives 5 (1):97-112. https://www.aeaweb.org/ articles?id=10.1257/jep.5.1.97.

Purwanto A (2013) Modal budaya dan sosial dalam industri seni kerajinan keramik Kasongan. Disertation, University of Indonesia, Depok.

Razin E (2002) Conclusion the economic context, embeddedness and immigrant entrepreneurs. International Journal of Entrepreneurial Behavior \& Research 8 (1/2):162-167. https://doi. org/10.1108/13552550210428061.

Rangkuti H (2016) The role of migration on poverty reduction in Indonesia: A quest on the migrants' welfare before and after migration. Article presented in the Asian Population Association (APA). [Accessed 08 May 2020]. https://iussp.org/sites/default/files/event_call_for_papers/paper\%20 Hasnani\%20Rangkuti\%20-\%20IUSSP\%20Busan.pdf.

Sasongko YAT \& Ekawati SW (2013) Diaspora Madura: Analisis modal sosial dalam usaha sektor informal oleh migran Madura di Kecamatan Tanah Sareal, kota Bogor, Jawa Barat. Jurnal Sosiologi Pedesaan Sodality 1 (1):52-63. 
Scott WR (2014) Institutions and Organizations: Ideas, Interest, and Identities. Los Angeles: Sage Publications.

Sukamdi \& Ghazy M (2015) Internal Migration in Indonesia. United Nations Population Fund (UNFA) Indonesia, Monograph Series No. 3.

Safitri YM \& Wahyuni ES (2013) Jaringan sosial dan strategi adaptasi tenaga kerjamigran asal Lampung di Desa Jayamukti, Kecamatan Cikarang Pusat, Kabuoatenn Bekasi, Provinsi Jawa Barat. Jurnal Sosiologi Pedesaan Sodality 1 (1):64-77.

Turner S (2007) Small-scale enterprise livelihoods and social capital in eastern Indonesia: Ethnic embeddedness and exclusion. The Professional Geographer 59 (4):407-420. https://doi.org/10.1111/ j.1467-9272.2007.00631.x.

Veciana JM (2007) Entrepreneurship as A Scientific Research Programme. In: Entrepreneurship: Concept, Theory and Perspective. Heidelberg: Springer.

Volery T (2007) Ethnic Entrepreneurship: A Theoretical Framework. In: Leo-Paul Dana (ed.). Handbook of Research on Ethnic Minority Entrepreneurship: A Co-Evolutionary View on Resource Management. Northampton: Edward Elgar Publishing Inc.

Waldinger R, Aldrich H, \& Ward R (1990) Ethnic Entrepreneur. Newbury Park. California: Sage Publications.

Yinger MJ (1985) Ethnicity. Annual Review of Sociology 11: 151-180. https://doi.org/10.1146/annurev. so.11.080185.001055. 